\title{
Effects of Nitrogen Rates and Time of Application on Yield of Maize: Rainfall Variability Influenced Time of $\mathbf{N}$ Application
}

\author{
Zerihun Abebe and Hailu Feyisa \\ Bako Agricultural Research Center, P.O. Box 03, West Shoa, Ethiopia \\ Correspondence should be addressed to Zerihun Abebe; baatiree@gmail.com
}

Received 14 February 2017; Revised 4 May 2017; Accepted 15 May 2017; Published 18 June 2017

Academic Editor: Manuel Tejada

Copyright (c) 2017 Zerihun Abebe and Hailu Feyisa. This is an open access article distributed under the Creative Commons Attribution License, which permits unrestricted use, distribution, and reproduction in any medium, provided the original work is properly cited.

\begin{abstract}
Despite the fact that maize productivity is relatively better than other major cereal crops, its current productivity is still far below its potential productivity. $\mathrm{N}$ rate and time of application are among the major abiotic factors limiting the productivity of the crop. Because of such gaps, the experiment was conducted at Bako Agricultural Research Center in 2013 and 2014 cropping seasons to determine optimum $\mathrm{N}$ rate and time of application. Four levels of $\mathrm{N}$ rates $\left(46,69,92\right.$, and $\left.115 \mathrm{~N} \mathrm{~kg} \mathrm{ha}^{-1}\right)$ and four levels $\left(T_{1}, T_{2}, T_{3}\right.$, and $T_{4}$ ) of different time of $\mathrm{N}$ application were arranged in factorial combinations. Moreover, previously recommended $\mathrm{N}$ and the control were arranged in a randomized complete block design with three replications. In 2013, the highest significant biomass yield $\left(21.2 \mathrm{tha}^{-1}\right.$ ) was obtained at $115 \mathrm{~N} \mathrm{~kg} \mathrm{ha}^{-1}$ and $T_{4}$ followed by $69 \mathrm{~N} \mathrm{~kg} \mathrm{ha}^{-1}$ at $T_{1}$ and $T_{2}$ and $92 \mathrm{~N} \mathrm{~kg} \mathrm{ha}^{-1}$ at $T_{2}$. In contrast, the highest grain yield in 2013 was obtained at $92 \mathrm{~N} \mathrm{~kg} \mathrm{ha}^{-1}$ at $T_{2}$ followed by $115 \mathrm{~N} \mathrm{~kg} \mathrm{ha}^{-1}$ at either $T_{2}$ or $T_{4}$ and $69 \mathrm{~N} \mathrm{~kg} \mathrm{ha}^{-1}$ at either $T_{1}$ or $T_{3}$ application time. Interestingly, a significant yield increase by $37 \%$ was obtained when $92 \mathrm{~N} \mathrm{~kg} \mathrm{ha}^{-1}$ at the time of $T_{2}$ was applied compared to previous recommended $110 \mathrm{~N} \mathrm{~kg} \mathrm{ha}^{-1}$ rate and time of application. In 2014, however, the highest yield was recorded when $92 \mathrm{~N} \mathrm{~kg} \mathrm{ha}^{-1}$ at $T_{1}$ was used. Application of $46 \mathrm{~N} \mathrm{~kg} \mathrm{ha}^{-1}$ at $T_{2}$ showed statistically similar yield performance when compared with previous $\mathrm{N}$ recommendation. The lowest yield was recorded from the control plot in both years. In 2013, the maximum net profit and acceptable marginal rate of return (MMR) were obtained when $92 \mathrm{~N} \mathrm{~kg} \mathrm{ha}^{-1}$ at $T_{2}$ was used for maize production during erratic and heavy rainfall distribution, particularly at a time of $\mathrm{N}$ application. However, the maximum net benefit $\left(30743 \mathrm{ETB} \mathrm{ha}^{-1}\right.$ ) and acceptable MRR could be obtained when $92 \mathrm{~N} \mathrm{~kg} \mathrm{ha}^{-1}$ at $T_{1}$ was used if the rainfall amount and distribution are relatively uniform. In conclusion, application of $92 \mathrm{~N} \mathrm{~kg} \mathrm{ha}^{-1}$ at $T_{1}$ (10-15 DAP and 35-40 DAP) is the best $\mathrm{N}$ rate and time of application in good rainy seasons and hence recommended for the end users. However, in the case of erratic and heavy rainy seasons, application of $92 \mathrm{~N} \mathrm{~kg} \mathrm{ha}^{-1}$ at three times application regimes (1/3 $\mathrm{N}$ at 10-15 days after planting (DAP), 1/3 N at 35-40 DAP and 55-60 DAP) should be used to get maximum profit and acceptable MRR.
\end{abstract}

\section{Introduction}

Maize (Zea mays) is one of the main and popular cereal crops due to its high value as stable food as well as its stover demand for animal feed and fuel and even for construction purposes [1]. Maize is also the most important stable crop in terms of calorie intake in Ethiopian rural families. Approximately $88 \%$ of maize produced in Ethiopia is used as food, in both green cobs and grain [2]. Because of its multiple advantages, it ranks second in production area next to teff while it ranks first in its productivity among major cereal crops [3] and it is, therefore, one of the high priority crops to feed the everincreasing Ethiopian population [2].
Despite the fact that its current productivity is higher than other major cereal crops, the yield productivity is below its potential. For instance, the potential yield of late maturing hybrid maize varieties can produce up to $9.5-12$ tha $^{-1}$ at research field and 6-8.5 $\mathrm{tha}^{-1}$ at an on-farm field [4] whereas the national average productivity is $3.2 \mathrm{tha}^{-1}$ [5]. Even though many biotic and abiotic factors can contribute to these big yield gaps, soil fertility depletion and poor nutrient management are among the major factors contributing to low productivity [6].

Nitrogen $(\mathrm{N})$ management in maize production system is one of the main concerns since it is the most important and primary nutrient for growth and development of the 
crop [7]. Hence, application of fertilizer $\mathrm{N}$ resulting in higher biomass is commonly increased. Optimum rate and time of $\mathrm{N}$ application can enhance yield productivity and nutrient use efficiencies while reducing the environmental pollution $[8,9]$. $\mathrm{N}$ application beyond the optimum requirement of maize could not increase yield and may lead to an elevated level of $\mathrm{NO}_{3}$ in the soil and susceptibility to $\mathrm{NO}_{3}$ loss by leaching [10]. Another report also indicated that abundant $\mathrm{N}$ supply favors $\mathrm{NH}_{3}$ losses, especially if the supply is in excess of plant requirements [11]. However, the negative environmental impacts associated with maize production can be minimized through efficient $\mathrm{N}$ management, including appropriate rate and time of $\mathrm{N}$ recommendation [11].

Time of $\mathrm{N}$ application at appropriate crop growth stage is also another main focus to enhance $\mathrm{N}$ use efficiency and increase maize productivity. All applied $\mathrm{N}$ is not absorbed by the crop since leaching is one of the main challenges for $\mathrm{N}$ loss in high rainfall areas. Research reports had shown that about $50 \%$ and even more than this figure at higher doses of applied $\mathrm{N}$ remain unavailable to a crop due to $\mathrm{N}$ loss through leaching [12]. This leaching loss may be determined by a quantity of $\mathrm{N}$ applied, inappropriate time of application, soil permeability, and quantity of rainfall drops in the area [11]. However, an optimum and efficient time of $\mathrm{N}$ application can increase the recovery of applied $\mathrm{N}$ up to $58-70 \%$ and hence increase yield and grain quality of the crop $[12,13]$.

Previous $\mathrm{N}$ recommendation for maize production in Western Ethiopia was $92-110 \mathrm{~kg} / \mathrm{ha}$, half at the time of planting and half at 30-35 days after planting [2] while applying all at planting is the best alternative to large scale maize farming where mechanization is available [14]. However, many research findings verified that $\mathrm{N}$ application at the time of maize planting is not efficiently recovered since nodal root growth and development from emergence up to 1-2 leaves' development stage is a very young stage [9]. The same author showed that seed emergence usually occurs in 6-8 days after planting while $12-15$ and 15-20 days after planting are needed to form one and two developed leaves for hybrid maize, respectively $[9,15]$. At these stages, the seedlings depend on kernel food reserve since nodal root development is not yet started for nutrient absorption. If $\mathrm{N}$ application, however, at maize planting is done, its loss through leaching and runoff can be articulated since its absorption by the crop up to $10-15$ days after planting is rare. Hence, application of $\mathrm{N}$ at the time of planting is easily lost through leaching or runoff in heavy rainfall areas and it not only is attributed to an environmental population but also results in nonprofit cost $[11,13,16]$, and hence the disadvantages of $\mathrm{N}$ application at the time of planting may outweigh its advantages. Therefore, the objective of this study was to investigate optimum rate and time of $\mathrm{N}$ application to increase optimum and economically profitable maize yield.

\section{Material and Methods}

The experiment was conducted at Bako Agricultural Research Center for two consecutive years (2013 and 2014), and it is located in a subhumid area of Western Ethiopia which lies at a latitude of $9 \mathrm{E} 6^{\prime} \mathrm{N}$ and longitude of $37 \mathrm{E} 9^{\prime} \mathrm{E}$ and at an altitude of $1650 \mathrm{~m}$ a.s.l. It has an annual mean minimum and maximum air temperatures of 13.5 and $29.7^{\circ} \mathrm{C}$, respectively. The area received an annual rainfall of $1431 \mathrm{~mm}$ (2013) and $1067 \mathrm{~mm}$ (2014) with maximum precipitation being received in the months of May-August.

The soil of Bako area is reddish-brown, nitosol. It is an acidic soil with a $\mathrm{pH}$ range of 4.5-5.6. The surrounding area is a mixed farming zone and is one of the most important maize (Zea mays L.) growing belts in Ethiopia, and cultivations of teff(Eragrostis tef), finger millet (Eleusine coronata), common bean (Phaseolus vulgaris L.), sorghum (Sorghum bicolor L.), noug (Guizotia abyssinica L.f.), and soybean (Glycine max L.) are common. The area is predominantly maize based monocropping with low soil fertility problem that directly influences production and productivity of the cultivated crops.

The treatments consisted of two factors, namely, four levels of $\mathrm{N}$ rates $\left(46,69,92\right.$, and $\left.115 \mathrm{~N} \mathrm{~kg} \mathrm{ha}^{-1}\right)$ and four different application times $\left(T_{1}=1 / 2 \mathrm{~N}\right.$ at $10-15$ days after planting (DAP) and $1 / 2 \mathrm{~N}$ at $35-40 \mathrm{DAP} ; \mathrm{T}_{2}=1 / 3 \mathrm{~N}$ at $10-15$ DAP, $1 / 3 \mathrm{~N}$ at 35-40 DAP, and $1 / 3 \mathrm{~N}$ at 55-60 DAP; $T_{3}=$ $1 / 3 \mathrm{~N}$ at 35-40 DAP, $1 / 3 \mathrm{~N}$ at 55-60 DAP, and 75-80 DAP; and $T_{4}=1 / 4 \mathrm{~N}$ at $10-15 \mathrm{DAP}, 1 / 4 \mathrm{~N}$ at $33-40 \mathrm{DAP}, 1 / 4 \mathrm{~N}$ at 55-60 DAP, and $1 / 4$ at $75-80 \mathrm{DAP}$ ) that were arranged in $4 \times 4$ factorial combinations. Moreover, previous rate and application time of $\mathrm{N}$ (referred as $R$ ) and the control plot receiving no $\mathrm{N}$ fertilizer were included for the comparisons purposes. A total of 16 treatment combinations plus previous recommended rate and time of $\mathrm{N}$ application and control plot without $\mathrm{N}$ were laid out using a randomized complete block design (RCBD) with three replications. Application time of $\mathrm{N}$ was done within the stated time ranges, but at the same date as per treatment arrangements.

The experimental plots were plowed three times at different time intervals starting from mid-May and leveled manually prior to field layout. Plant population for all experimental plots was 44444 plants ha ${ }^{-1}, 75 \mathrm{~cm}$ between rows and $30 \mathrm{~cm}$ between plants. Recommended phosphorus $\left(20 \mathrm{~kg} \mathrm{Pha}^{-1}\right)$ in the form of triple superphosphate (TSP) for all experimental plots including standard check and control plot was equally and uniformly applied at the time of maize planting. $\mathrm{N}$ was applied in the form of UREA as per treatment arrangements. One hybrid long maturing variety (BH661) of maize was used for the execution of the treatments. Its yield potential varies between 9.5 and 12 tha $^{-1}$ at research field and 6 and 8.5 tha $^{-1}$ at farmers' field under integrated agronomic managements. The variety was released by Bako National Maize Research Center in 2011 and it can be grown in a range of 1600-2200 $\mathrm{m}$ above sea level and it requires an annual rainfall of 1000-1500 with uniform distribution in its growing periods. The trial was planted on May 30th in the 2013 and June 1st in 2014. Other agronomic managements rather than treatment variations were uniformly applied to all experimental plots.

At the time of harvesting, the maize was harvested by excluding two border rows from each side. A net plot size for each plot was $2.25 \mathrm{~m} \times 5.1 \mathrm{~m}\left(11.475 \mathrm{~m}^{2}\right)$. Stand counts per net plot were counted at the time of harvesting. Finally, 
TABLE 1: Analysis of variance for yield and yield components of maize as influenced by $\mathrm{N}$ rates, time of application, and the interaction effects in 2013 and 2014 at Bako, Western Ethiopia.

\begin{tabular}{|c|c|c|c|c|c|}
\hline \multirow{2}{*}{ Sources of variations } & \multirow{2}{*}{ D.f. } & \multicolumn{4}{|c|}{$F$ probability $(P=0.05)$} \\
\hline & & Biomass & Grain yield & HI & $\mathrm{AE}$ \\
\hline Year (Yr) & 1 & $<.001$ & $<.001$ & $<.001$ & $<.001$ \\
\hline Nitrogen $(\mathrm{N})$ & 3 & $<.001$ & $<.001$ & 0.012 & $<.001$ \\
\hline Time of application (TA) & 3 & 0.277 & 0.083 & 0.81 & 0.063 \\
\hline $\mathrm{Yr} \times \mathrm{N}$ & 3 & 0.193 & 0.001 & 0.008 & $<.001$ \\
\hline $\mathrm{Yr} \times \mathrm{TA}$ & 3 & 0.093 & 0.054 & 0.126 & 0.106 \\
\hline $\mathrm{N} \times \mathrm{TA}$ & 9 & $<.001$ & 0.047 & 0.004 & 0.164 \\
\hline $\mathrm{Yr} \times \mathrm{N} \times \mathrm{TA}$ & 9 & $<.001$ & 0.024 & 0.062 & 0.159 \\
\hline Replication & 2 & 0.155 & 0.116 & 0.271 & 0.121 \\
\hline Residual & 62 & - & - & - & - \\
\hline Total & 95 & & & & \\
\hline SE & & 1.893 & 0.724 & 3.36 & 0.0113 \\
\hline $\mathrm{CV}(\%)$ & & 8.6 & 7.6 & 7.6 & 8.6 \\
\hline
\end{tabular}

HI: harvest index; AE: agronomic efficiency.

biomass yield, grain yield, harvest index, and other important agronomic traits were collected. Maize grain yield was adjusted to standard moisture contents to $10 \%$ as described as follows: adjusted yield $=$ actual yield $\times 100-M / 100-$ $D$, where $M$ and $D$ are measured and standard moisture contents, respectively. Agronomic efficiency was calculated as yield obtained per $\mathrm{N}$ applied. Costs that vary among treatments were also assessed. The cost of UREAa, the cost of labor required for the application, and cost for shelling were estimated by assessing the current local market prices. The price of UREA (1600 ETB $100 \mathrm{~kg}^{-1}$ ) and daily labors (35 ETB per one person day based on government's current scale in the study area) and the cost of maize shelling (100 ETB tha $\left.{ }^{-1}\right)$ were considered to get the total cost that varied among the treatments. Time elapsed during UREA application for some plots of each treatment was recorded to calculate daily labor required for one hectare. One person per day was estimated based on eight working hours per day. However, other nonvaried costs were not included since all agronomic managements were equally and uniformly applied to each experimental plot. Before calculating gross revenue, maize yields obtained from each experimental plot were adjusted down by $10 \%$. Finally, gross revenue was calculated as total yield obtained multiplied by field price (3800 ETB 1 tha $^{-1}$ ). The net benefit and the marginal rate of return (MRR) were also calculated as per standard manual [17]. Finally, combined analyses of variance (ANOVA) across seasons were carried out using Gen Stat 15th edition software, and the Duncan multiple range test at $P<0.05$ was used for comparing treatment means. Sigma plot version 10 was used for graphing and error bar for each treatment mean was also plotted.

\section{Results}

The result of combined analysis revealed that seasonal variations highly $(P<0.001)$ affected biomass, grain yield, harvest index, and agronomic efficiency of the crop (Table 1). Even though main effects of time of $\mathrm{N}$ application did not show significant variation to all parameters, there were highly significant effects due to the various applications of $\mathrm{N}$ rates. Moreover, the effect of $\mathrm{N}$ rate and time of application significantly affected biomass yield and harvest index while this interaction due to seasonal variations significantly affected both maize biomass and grain yield (Table 1). Therefore, separate analysis for each season was done since the seasonal rainfall variability considerably affected the response of treatments.

As depicted in Figure 2(a), application of N significantly affected the mean yield of maize. The highest significant mean yields $\left(9.8\right.$ tha $^{-1}$ ) in 2013 were obtained when $92 \mathrm{~N} \mathrm{~kg} \mathrm{ha}^{-1}$ followed by $115 \mathrm{~N} \mathrm{~kg} \mathrm{ha}^{-1}$ was applied, but both are statistically at par. In addition, statistically comparable yield performance was obtained when $69 \mathrm{~N} \mathrm{~kg} \mathrm{ha}^{-1}$ was applied compared to 92 and $115 \mathrm{~N} \mathrm{~kg} \mathrm{ha}^{-1}$ applications. However, more than $23 \%$ and $45 \%$ significant yield increases were recorded when $\mathrm{N}$ at $92 \mathrm{kgha}^{-1}$ was applied compared to $46 \mathrm{~N} \mathrm{~kg} \mathrm{ha}^{-1}$ and the control plot receiving no $\mathrm{N}$ application. In contrary, the lowest significant yield, except the control, was recorded when $110 \mathrm{~N} \mathrm{~kg} \mathrm{ha}^{-1}$ was applied as compared to other $\mathrm{N}$ rates. In 2013 season, the amount and the distribution of rainfall during the growing period of the crop were much higher than in 2014. The cumulative rainfall in the entire growing period, particularly from mid-June to August, was considerably higher in the 2013 (Figure 3(a)) than in 2014. Moreover, the daily rainfall distribution, particularly from early June to late august, was erratic and sometimes heavy rain, causing high runoff and even leading to leaching, occurred in 2013 (Figure 3(b)) compared to 2014.

In 2014, however, the response of maize yield to the main effect of $\mathrm{N}$ application rate did not show significant variations due to the application of $46,69,92$ and $115 \mathrm{~N} \mathrm{~kg} \mathrm{ha}^{-1}$ though the highest grain yield was obtained when $69 \mathrm{~N} \mathrm{~kg} \mathrm{ha}^{-1}$ was applied (Figure 2(a)). The lowest yield was, however, recorded from the control plot without N. Even though the yield responses of maize to $110 \mathrm{~N} \mathrm{~kg} \mathrm{ha}^{-1}$ were significantly better 


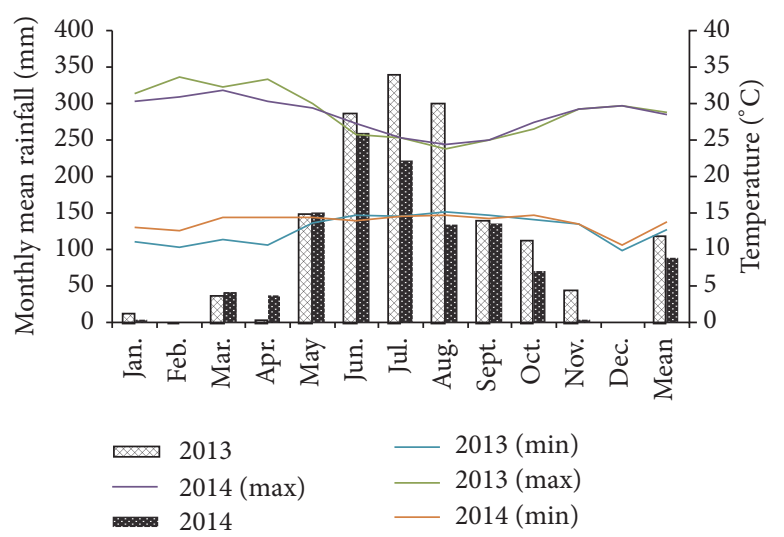

FIGURE 1: Mean monthly rainfall and minimum and maximum temperature of Bako research site, 2013-2014.

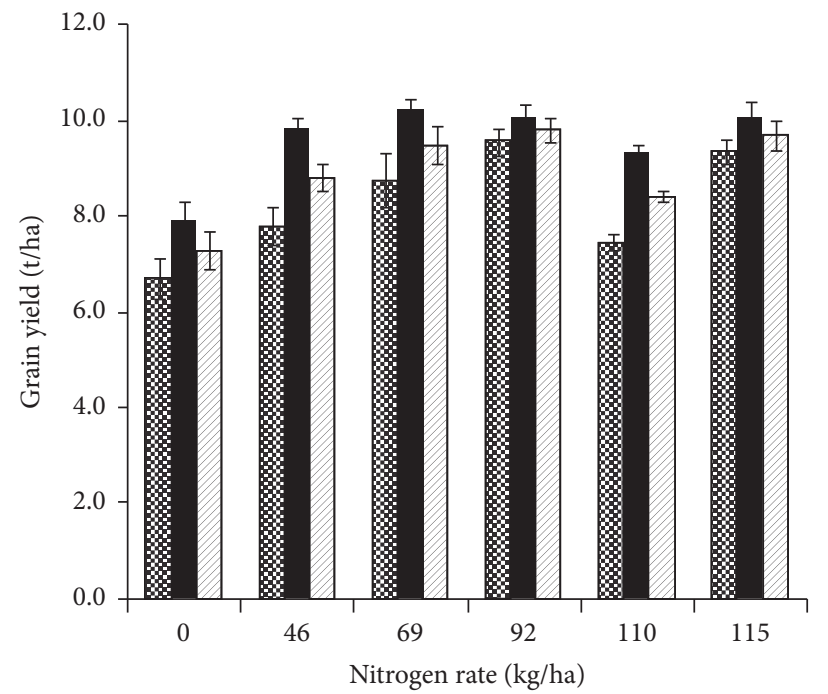

Q 2013

- 2014

๑ Mean

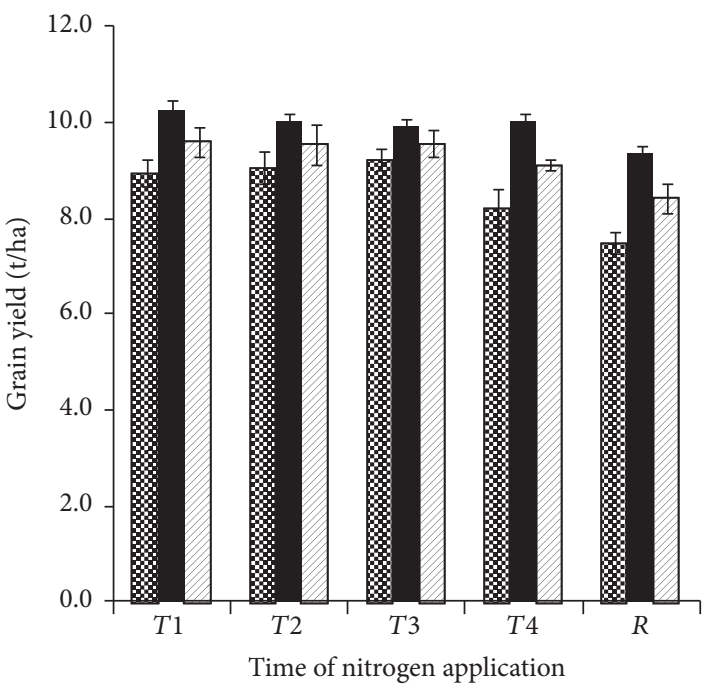

\% 2013

- 2014

$\square$ Mean

(a)

(b)

FIGURE 2: The effect of nitrogen rates (a) and application time (b) on the yield of maize in the 2013 and 2014 cropping seasons at Bako, Western Ethiopia.

in 2014 than in 2013, significantly lower yield except $\mathrm{N}$ control plot was recorded as compared to other $\mathrm{N}$ rates. This could be related to the annual or monthly amount (Figure 1) and cumulative and daily distribution of the rainfall in 2014 . For instance, the monthly amount of rainfall from June to August in 2014 was significantly lower than during 2013 rainy season.

Application time of $\mathrm{N}$ was significantly varied across seasons (Figure 2(b)). The highest yield in 2013 was obtained at $T_{3}$ followed by $T_{2}$ and $T_{1}$, but all are statistically at par. However, the lowest yield was attained at $R$ (previous recommendation) followed by $T_{4}$. The highest yield, however, was recorded at $T_{1}$ in 2014 though all treatment means were statistically similar. These response variations across the seasons might also relate to rainfall amount and distributions (Figures 1 and 3).

Nitrogen rates by time of application also showed significant effects on both biomass and grain yield of maize in each season (Figure 4). In 2013, the highest significant biomass yield (21.2 tha ${ }^{-1}$ ) was obtained at $115 \mathrm{~N} \mathrm{~kg} \mathrm{ha}^{-1}$ and $T_{4}$ (four times split application of equal doses) followed by $69 \mathrm{~N} \mathrm{~kg} \mathrm{ha}^{-1}$ at $T_{1}$ and $T_{2}$ and $92 \mathrm{~N} \mathrm{~kg} \mathrm{ha}^{-1}$ at $T_{2}$, which are statistically at par. However, application of $69 \mathrm{~kg} \mathrm{ha}^{-1}$ at $T_{4}$ and $46 \mathrm{~kg} \mathrm{ha}^{-1}$ at $T_{2}$ or $T_{4}$ showed the lowest yield, except the control plot without $\mathrm{N}$, compared to other treatment combinations and even with previous recommendation. The result revealed that more than $20 \%$ and $19 \%$ biomass yield advantages were obtained for $69 \mathrm{~N} \mathrm{~kg} \mathrm{ha}^{-1}$ at $T_{3}$ and $T_{1}$ or 


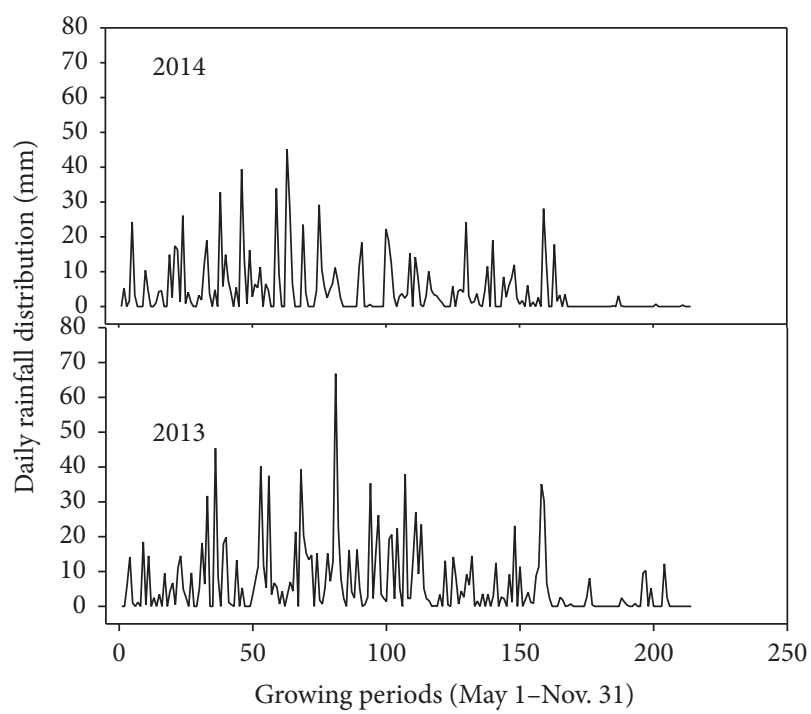

(a)

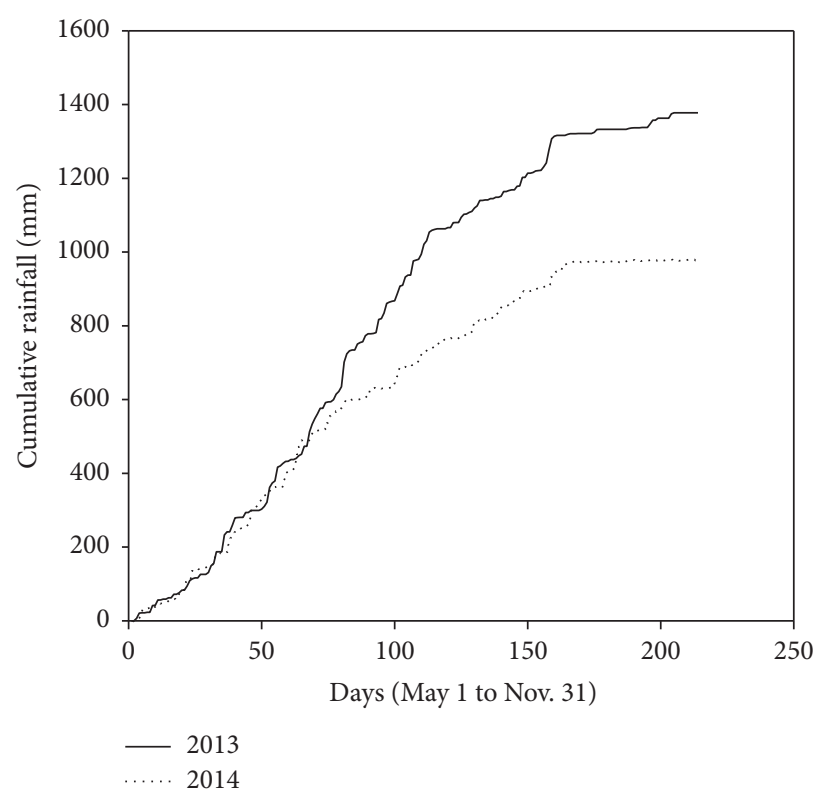

(b)

FIGURE 3: Daily rainfall distribution (a) and cumulative rainfall (b) received in growing periods of 2013 and 2014 rainy seasons at Bako, Western Ethiopia.

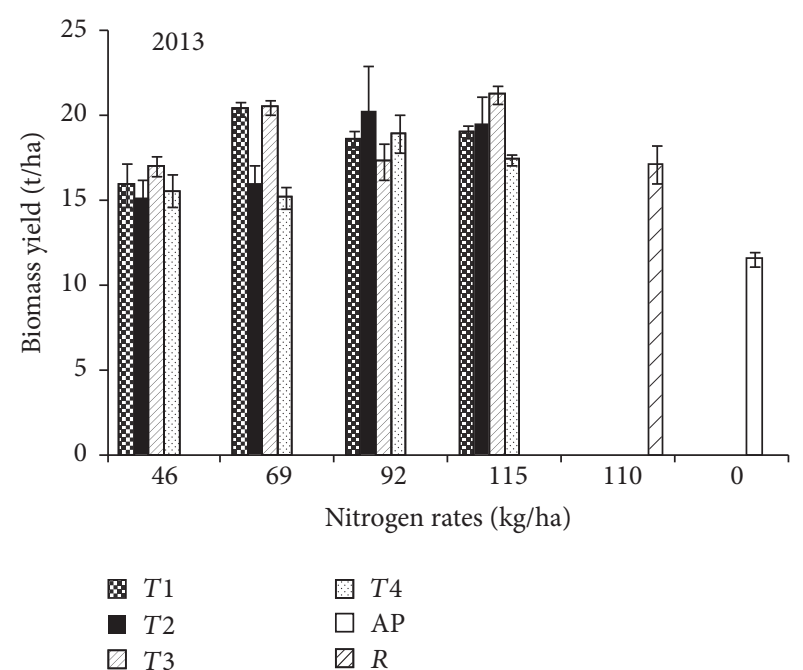

(a)

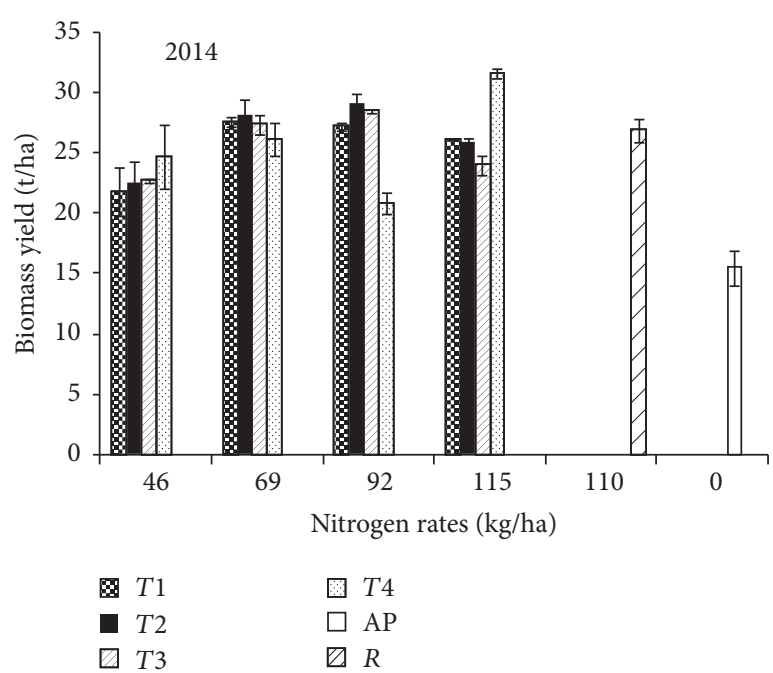

(b)

FIGURE 4: The effect of $\mathrm{N}$ rate and time of application on biomass yield of maize in the 2013 and 2014 rainy seasons.

$92 \mathrm{~N} \mathrm{~kg} \mathrm{ha}^{-1}$ at $T_{3}$ compared to $110 \mathrm{~N} \mathrm{kgaha}^{-1}$, half of the total at planting and the remaining at knee height. This result may be related to rainfall amount and distribution that may lead to runoff and leaching due to mismatch $\mathrm{N}$ application and time of crop $\mathrm{N}$ demand. The lowest and significant biomass yield was recorded from control plot.

The overall means regardless of treatment variations revealed that significantly higher biomass yield $\left(2.5 \mathrm{tha}^{-1}\right)$ was obtained in the 2014 than in $2013\left(1.7\right.$ tha $\left.^{-1}\right)$. This variation might be related to the effect of rainfall amount and distribution during the growing seasons (Figures 1 and 3).
In addition to higher monthly rainfall amount in pick rainy seasons, regarding rainfall distribution (Figures 1 and 3), the cumulative rainfall in different proposed application time was considerably higher in 2013 than 2014 (Figure 5), which may favor $\mathrm{N}$ losses through runoff and leaching. Similar to the result observed in 2013, the highest and significant biomass yield was obtained at a rate of $115 \mathrm{~N} \mathrm{~kg} \mathrm{ha}^{-1}$ and $T_{4}$ in the 2014 , and more than $17 \%$ and $100 \%$ yield advantage were obtained when compared with previously recommended rate and time of $\mathrm{N}$ application and the control plot (Figure 5), respectively. Application of $69 \mathrm{~N} \mathrm{~kg} \mathrm{ha}^{-1}$ at $T_{1}$ or $T_{2}$ and $92 \mathrm{~N} \mathrm{~kg} \mathrm{ha}^{-1}$ at 


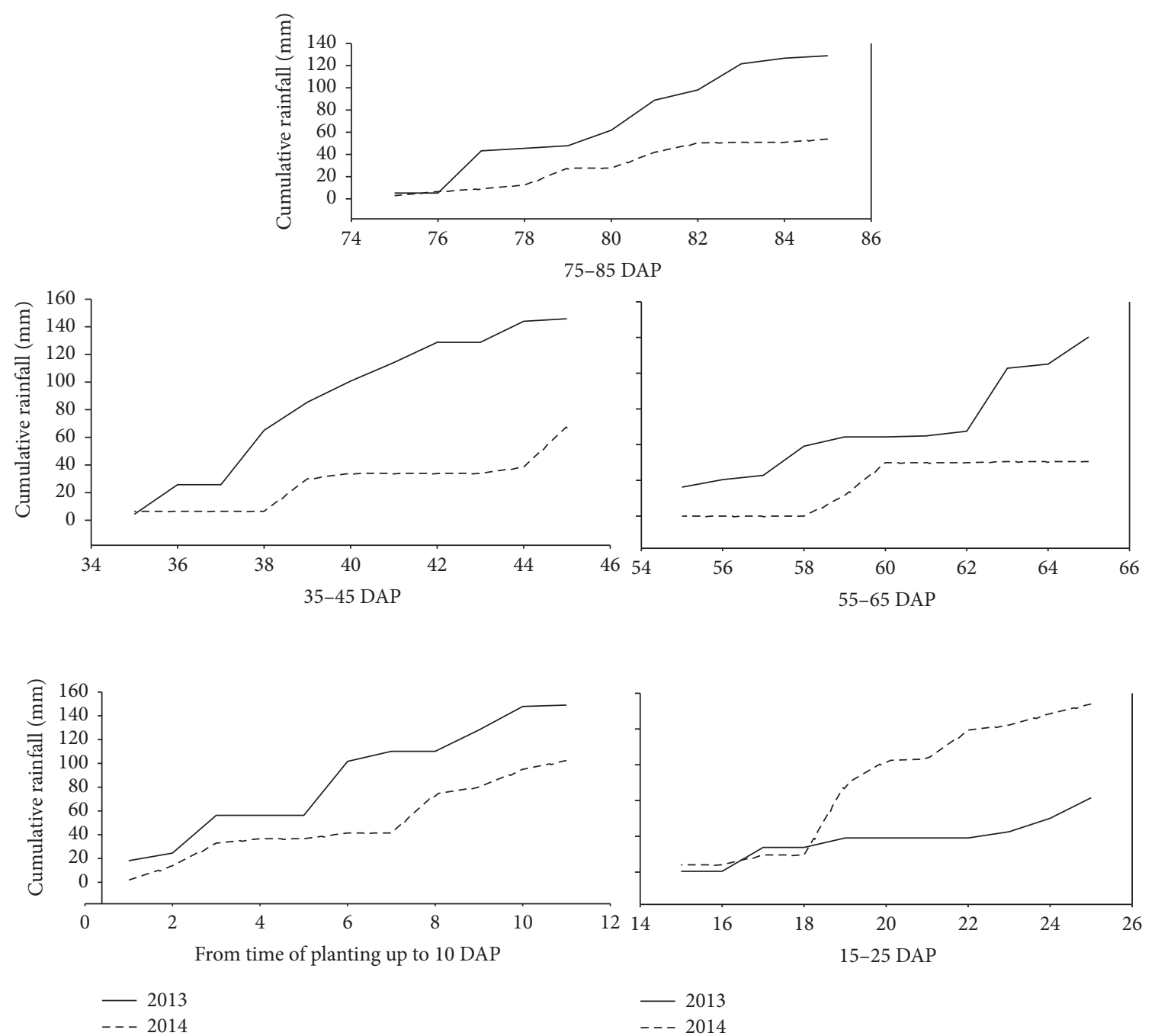

FIGURE 5: Cumulative rainfall distribution in different proposed $\mathrm{N}$ application times in 2013 and 2014 rainy seasons.

$T_{2}$ statistically showed the next highest biomass even though these means are at parity with previous recommendation $\left(110 \mathrm{~N} \mathrm{~kg} \mathrm{ha}^{-1}\right.$ at $R$ ). The lowest yield, except the control plot, was recorded when $115 \mathrm{~N} \mathrm{~kg} \mathrm{ha}^{-1}$ at $T_{4}$ was practiced.

Maize yield response to $\mathrm{N}$ rates and time of application was also significantly varied across seasons (Figure 6). The highest grain yield in 2013 was obtained when $92 \mathrm{~N} \mathrm{~kg} \mathrm{ha}^{-1}$ at $T_{2}$ followed by $115 \mathrm{~N} \mathrm{~kg} \mathrm{ha}^{-1}$ at either $T_{2}$ or $T_{4}$ and $69 \mathrm{~N} \mathrm{~kg} \mathrm{ha}^{-1}$ at either $T_{1}$ or $T_{3}$ applications time were practiced, but all means are statistically at par. The lowest yield, except the control plot, was recorded when $46 \mathrm{~N} \mathrm{~kg} \mathrm{ha}^{-1}$ followed by $69 \mathrm{~N} \mathrm{~kg} \mathrm{ha}^{-1}$ at $T_{4}$ was used. Interestingly, a significant yield increase by $29.7 \%$ and $24.4 \%$ was obtained when $69 \mathrm{~N} \mathrm{~kg} \mathrm{ha}^{-1}$ at the time of $T_{1}$ and $T_{3}$ was applied compared to the application of $110 \mathrm{~N} \mathrm{~kg} \mathrm{ha}^{-1}$; half at the time of planting and the remaining at the knee height were applied. The lowest, however, grain yield was recorded from control plot receiving no $\mathrm{N}$ fertilizer (Figure 6).

Similar to biomass yield, significantly higher grain yield was recorded in $2014\left(9.9 \mathrm{tha}^{-1}\right)$ than in $2013\left(8.7 \mathrm{tha}^{-1}\right)$. The highest yields in 2014 were also recorded when $92 \mathrm{~N} \mathrm{~kg} \mathrm{ha}^{-1}$ at $T_{1}$ followed by $115 \mathrm{~N} \mathrm{~kg} \mathrm{ha}^{-1}$ at $T_{4}$ and $69 \mathrm{~N} \mathrm{~kg} \mathrm{ha}^{-1}$ at $T_{1}$ was used although all of these means are statistically similar (Figure 6). The lower rate of $\mathrm{N}\left(46 \mathrm{~kg} \mathrm{ha}^{-1}\right)$ at $T_{2}$ showed similar yield performance compared to the highest three treatment means. Interestingly, application of $46 \mathrm{~N} \mathrm{~kg} \mathrm{ha}^{-1}$ at $T_{2}$ showed statistically similar yield performance, though with $10 \%$ yield advantage, when compared with the application of previously recommended $110 \mathrm{~N} \mathrm{~kg} \mathrm{ha}^{-1}$ and when half of the total $\mathrm{N}$ at planting and the remaining half at the stage of knee height were applied (Figure 6). Moreover, more than 14\% yield increase could be obtained when the application of either $69 \mathrm{~N} \mathrm{~kg} \mathrm{ha}^{-1}$ or $92 \mathrm{~N} \mathrm{~kg} \mathrm{ha}^{-1}$ at $T_{1}$ was practiced compared to previous $\mathrm{N}$ rate and time of application (Figure 6). The lowest yield was, however, recorded from control plot receiving no N.

Conversely, the highest and significant harvest index (HI) was recorded from the control plot without $\mathrm{N}$ (Figure 7) in each cropping season. Application of $46 \mathrm{~N} \mathrm{~kg} \mathrm{ha}^{-1}$ at $T_{2}$ and $115 \mathrm{~N} \mathrm{~kg} \mathrm{ha}^{-1}$ at $T_{4}$ showed the next significant $\mathrm{HI}$ in 


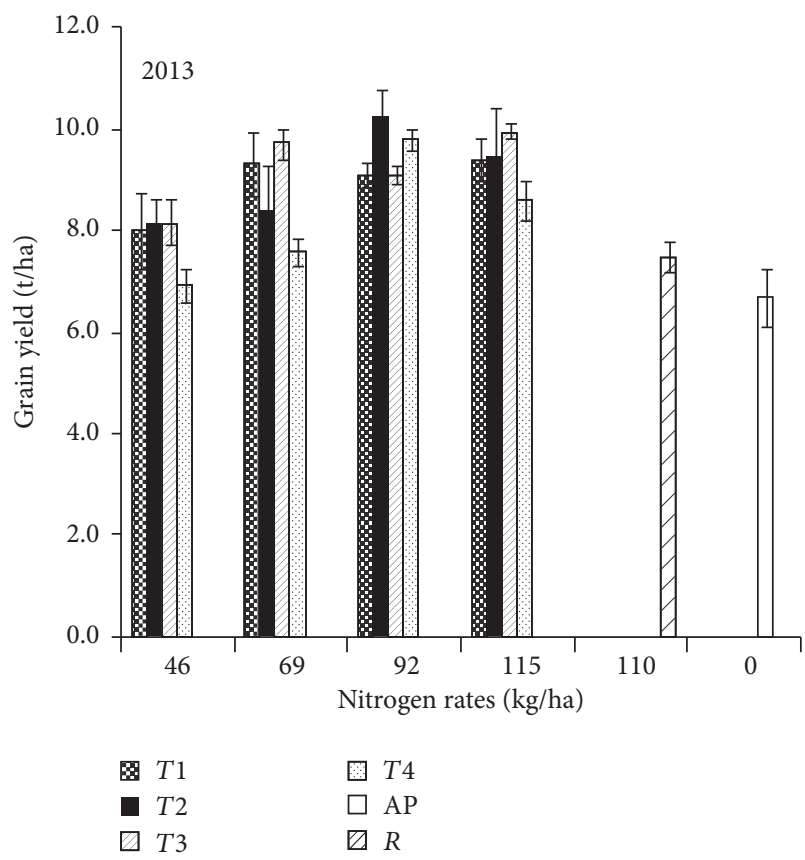

(a)

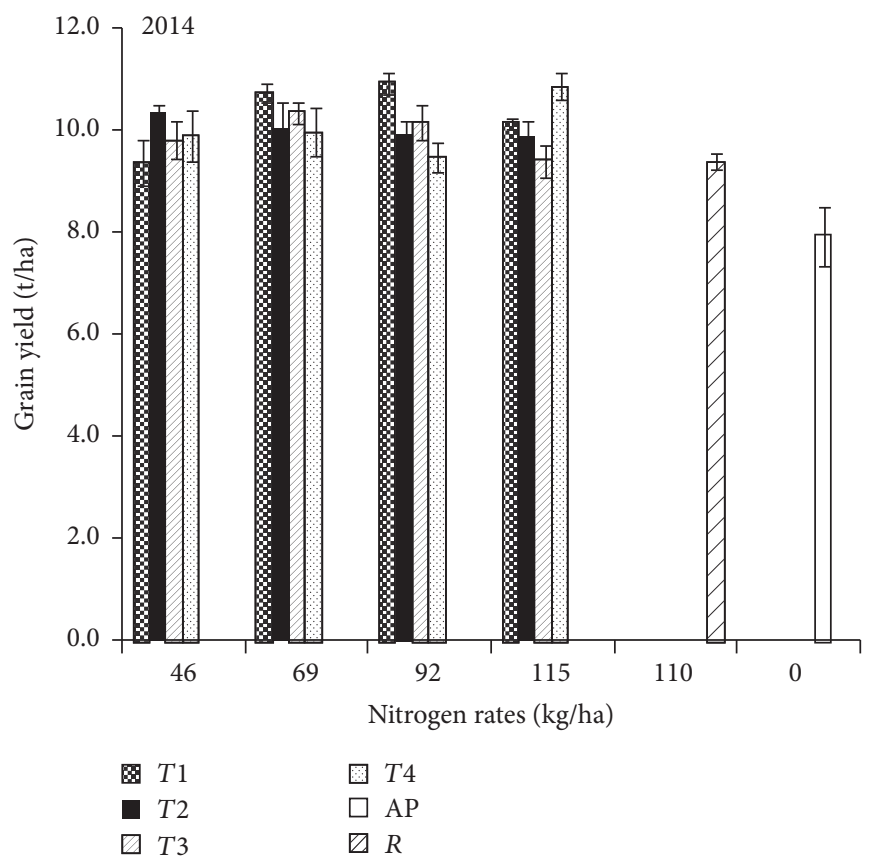

(b)

Figure 6: The effect of $\mathrm{N}$ rate and time of application on grain yield of maize in the 2013 and 2014 cropping seasons at Bako, Western Ethiopia.

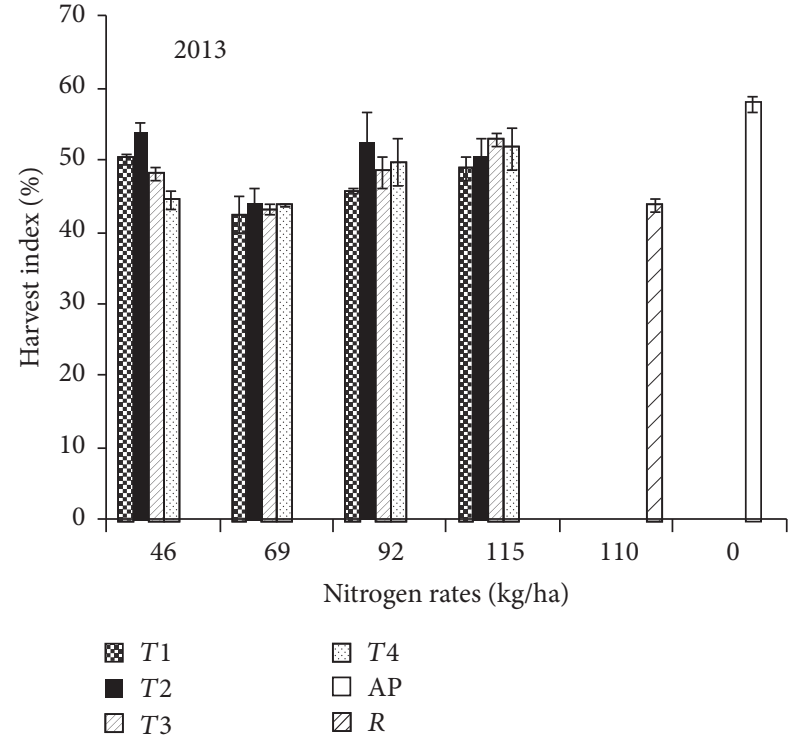

(a)

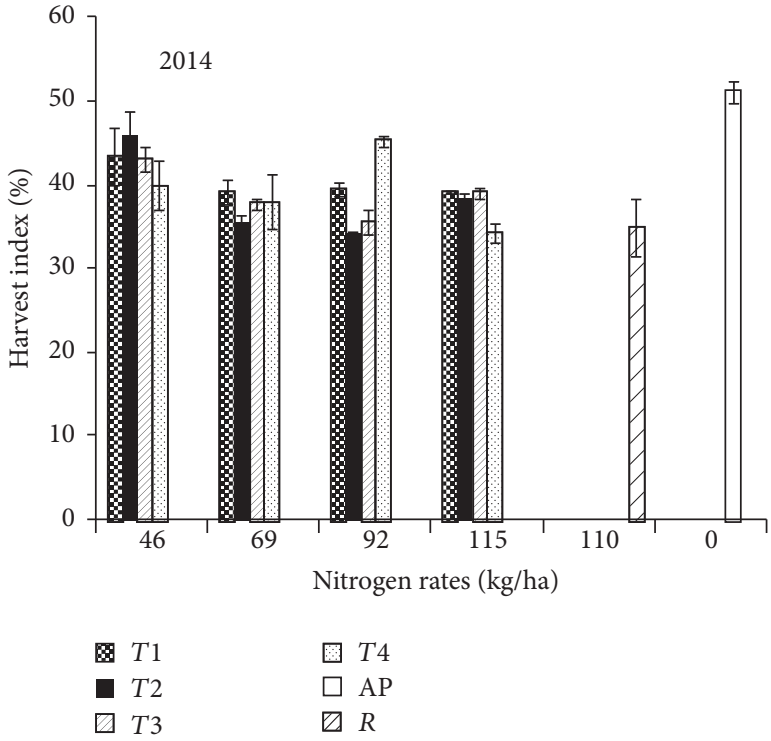

(b)

FIGURE 7: The effect of $\mathrm{N}$ rate and time of application on harvest index of maize in 2013 and 2014 cropping seasons.

2013 whereas $46 \mathrm{~N} \mathrm{~kg} \mathrm{ha}^{-1}$ at $T_{2}$ and $92 \mathrm{~N} \mathrm{~kg} \mathrm{ha}^{-1}$ at $T_{4}$ also showed the next significant HI in 2014 compared to other treatment means. However, previously recommended $\mathrm{N}$ and time of application showed significantly lower HI compared to different $\mathrm{N}$ rates and time of the applications (Figure 7).

Agronomic efficiency (AE) of the crop as affected by $\mathrm{N}$ rates indicated that the highest and significant $\mathrm{AE}$ was recorded at the lowest $\mathrm{N}$ rate and $\mathrm{AE}$ was linearly decreased as the function of $\mathrm{N}$ rate increased (Figure $8(\mathrm{a})$ ). However, the AE was not significantly varied due to the difference in time of application from $T_{1}$ to $T_{4}$ (Figure 8(b)). Significantly the lowest HI was, however, recorded from the previously recommended time of application $(R)$.

Even though both biomass and grain yield of maize were minimum at lower $\mathrm{N}$ rate $\left(46 \mathrm{~N} \mathrm{~kg} \mathrm{ha}^{-1}\right)$, the highest and significant agronomic efficiency (AE) was recorded at a lower rate and there were decreased trends as the function of $\mathrm{N}$ rates increased from 46 to $115 \mathrm{~N} \mathrm{~kg} \mathrm{ha}^{-1}$ (Figure 8). However, time 


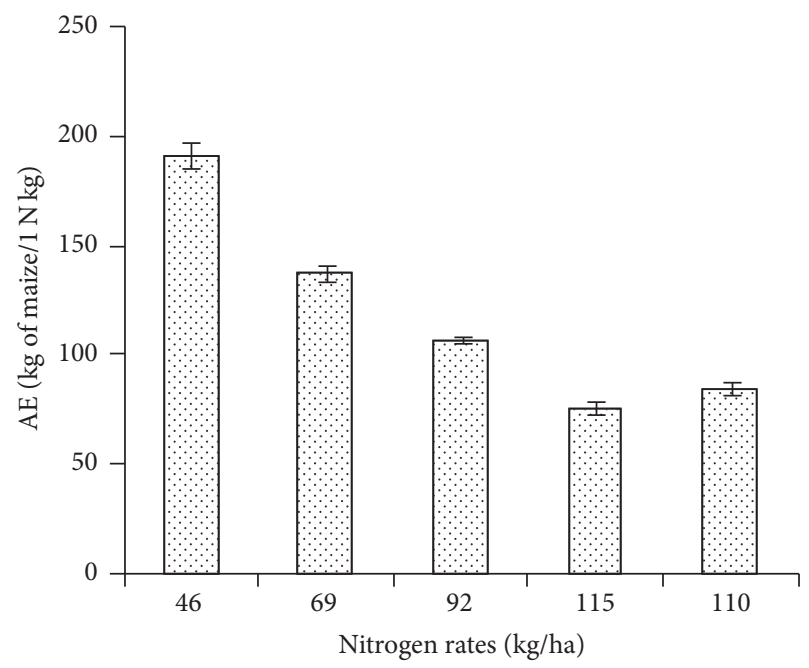

(a)

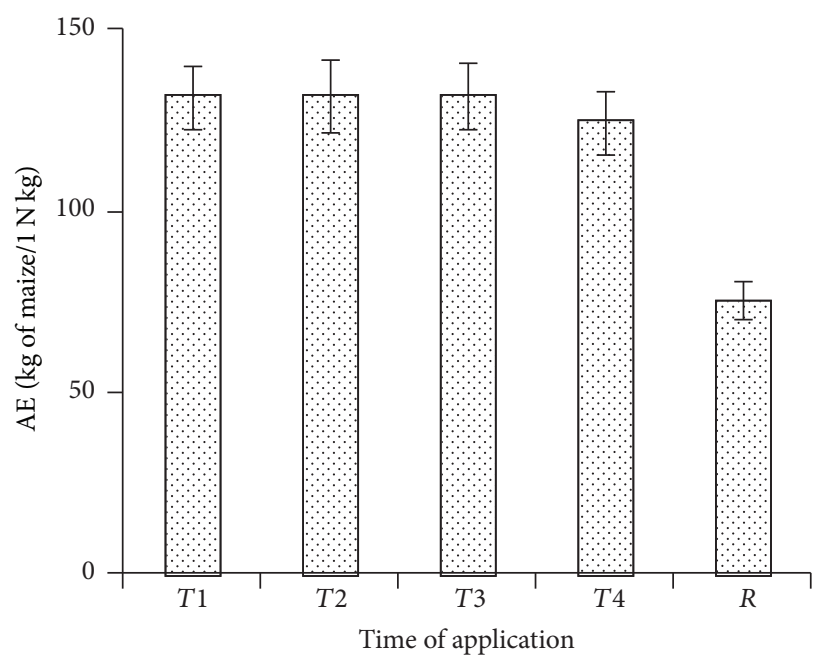

(b)

FIGURE 8: The effect of $\mathrm{N}$ rate (a) and time of application (b) on combined means of agronomic efficiency of maize.

TABle 2: Partial and marginal analysis as affected by $\mathrm{N}$ rates and time of application on maize in 2013 and 2014 cropping seasons.

\begin{tabular}{|c|c|c|c|c|c|c|c|c|c|c|c|c|c|c|}
\hline \multicolumn{2}{|c|}{ Trt } & \multirow{2}{*}{ TC } & \multicolumn{6}{|c|}{2013} & \multicolumn{6}{|c|}{2014} \\
\hline $\mathrm{N}$ & $\mathrm{TA}$ & & Yd & Ayd & GB & NB & DA & MRR & Yd & Ayd & GB & NB & DA & MRR \\
\hline \multicolumn{2}{|c|}{ Control } & 2503 & 6.7 & 6.0 & 22880 & 20377 & - & - & 7.9 & 7.1 & 27070 & 24568 & - & - \\
\hline 46 & $T_{1}$ & 4829 & 8.0 & 7.2 & 27360 & 22531 & - & 92.6 & 9.4 & 8.4 & 32031 & 27201 & - & 113 \\
\hline 46 & $T_{2}$ & 5318 & 8.2 & 7.4 & 27876 & 22558 & - & 5.53 & 10.3 & 9.3 & 35262 & 29944 & - & 561 \\
\hline 46 & $T_{3}$ & 5488 & 8.2 & 7.4 & 27930 & 22441 & $\mathrm{D}$ & - & 9.8 & 8.8 & 33486 & 27998 & $\mathrm{D}$ & - \\
\hline 69 & $T_{1}$ & 5695 & 9.3 & 8.4 & 31895 & 26200 & - & 967 & 9.3 & 8.4 & 31895 & 26200 & $\mathrm{D}$ & - \\
\hline 46 & $T_{4}$ & 5760 & 6.9 & 6.2 & 23683 & 17923 & $\mathrm{D}$ & - & 9.9 & 8.9 & 33775 & 28015 & $\mathrm{D}$ & - \\
\hline 69 & $T_{2}$ & 6076 & 8.4 & 7.6 & 28760 & 22684 & $\mathrm{D}$ & & 8.4 & 7.6 & 28760 & 22684 & $\mathrm{D}$ & - \\
\hline 69 & $T_{3}$ & 6332 & 9.7 & 8.8 & 33276 & 26944 & - & 117 & 10.7 & 9.6 & 36581 & 30250 & - & 30.2 \\
\hline 92 & $T_{1}$ & 6448 & 9.1 & 8.2 & 31195 & 24747 & $\mathrm{D}$ & - & 10.9 & 9.8 & 37191 & 30743 & - & 423 \\
\hline 69 & $T_{4}$ & 6548 & 7.6 & 6.8 & 25903 & 19355 & $\mathrm{D}$ & - & 10.0 & 9.0 & 34276 & 27728 & $\mathrm{D}$ & - \\
\hline 110 & $R$ & 6659 & 7.3 & 6.6 & 24898 & 18239 & $\mathrm{D}$ & - & 9.4 & 8.4 & 32060 & 25401 & $\mathrm{D}$ & - \\
\hline 92 & $T_{2}$ & 6904 & 10.3 & 9.2 & 35129 & 28225 & - & 224 & 9.9 & 8.9 & 33858 & 26954 & $\mathrm{D}$ & - \\
\hline 92 & $T_{3}$ & 7059 & 9.1 & 8.2 & 31155 & 24097 & $\mathrm{D}$ & - & 10.2 & 9.1 & 34714 & 27655 & $\mathrm{D}$ & - \\
\hline 115 & $T_{1}$ & 7193 & 9.4 & 8.5 & 32150 & 24957 & $\mathrm{D}$ & - & 10.1 & 9.2 & 34647 & 27454 & $\mathrm{D}$ & - \\
\hline 92 & $T_{4}$ & 7375 & 9.8 & 8.8 & 33477 & 26102 & $\mathrm{D}$ & - & 9.5 & 8.5 & 32309 & 24933 & $\mathrm{D}$ & - \\
\hline 115 & $T_{2}$ & 7630 & 9.5 & 8.5 & 32362 & 24732 & $\mathrm{D}$ & - & 9.9 & 8.9 & 33764 & 26134 & $\mathrm{D}$ & - \\
\hline 115 & $T_{3}$ & 7821 & 10.0 & 9.0 & 34079 & 26258 & $\mathrm{D}$ & - & 9.4 & 8.5 & 32099 & 24278 & $\mathrm{D}$ & - \\
\hline 115 & $T_{4}$ & 8143 & 8.6 & 7.8 & 29478 & 21335 & $\mathrm{D}$ & - & 10.8 & 9.8 & 37071 & 28928 & $\mathrm{D}$ & - \\
\hline
\end{tabular}

Trt = treatment combinations, $\mathrm{N}=$ nitrogen rate $(\mathrm{kg} / \mathrm{ha}), \mathrm{TA}=$ time of $\mathrm{N}$ application, $\mathrm{TC}=$ total cost that varied among treatments $\left(\mathrm{ETB}\right.$ ha $\left.{ }^{-1}\right), \mathrm{Yd}=\mathrm{yield}$ of maize $(\mathrm{t} / \mathrm{ha})$, Ayd = adjusted yield of maize $(\mathrm{t} / \mathrm{ha}), \mathrm{GB}=$ gross benefit $\left(\mathrm{ETB} \mathrm{ha}^{-1}\right), \mathrm{NB}=$ net benefit $\left(\mathrm{ETB} \mathrm{ha}^{-1}\right), \mathrm{DA}=$ dominance analysis, MRR $=$ marginal rate of return (\%), $\mathrm{D}=$ dominated, $R=$ previously recommended time of $\mathrm{N}$ application, and $1 \mathrm{USD}=22.50 \mathrm{ETB}$.

of application except the recommended one $(R)$ did not show any significant variation among the treatment means.

Partial and marginal analysis for means of treatment combinations against the previous recommendation and the control were carried out (Table 2). The result indicated that both partial and marginal analysis showed differences in each cropping season since the yield responses to the treatments were different across the seasons. In 2013 season, the highest net benefit (28225 $\mathrm{ETB} \mathrm{ha}^{-1}$ ) was obtained when $92 \mathrm{~N} \mathrm{~kg} \mathrm{ha}^{-1}$ at $T_{2}$ was carried out although the use of $69 \mathrm{~N} \mathrm{~kg} \mathrm{ha}^{-1}$ at $T_{3}$ followed by $69 \mathrm{~N} \mathrm{~kg} \mathrm{ha}^{-1}$ at $T_{1}$ gave the next maximum net benefit. However, the maximum net profit and acceptable marginal rate of return (MMR) were obtained when $92 \mathrm{~N} \mathrm{~kg} \mathrm{ha}^{-1}$ at $T_{2}$ was used for maize production during erratic and heavy rainfall distribution. In 2014 cropping season, however, the maximum net benefit was $30743 \mathrm{ETB} \mathrm{ha}^{-1}$ followed by $30250 \mathrm{ETBha}^{-1}$ and $29944 \mathrm{ETB} \mathrm{ha}^{-1}$ which were achieved when $92 \mathrm{~N} \mathrm{~kg} \mathrm{ha}^{-1}$ at $T_{1}, 69 \mathrm{~N} \mathrm{kgha}^{-1}$ at $T_{3}$, and 
$46 \mathrm{~N} \mathrm{~kg} \mathrm{ha}^{-1}$ at $T_{2}$ were, respectively, applied. However, the analysis of MRR showed that application of $92 \mathrm{~N} \mathrm{~kg} \mathrm{ha}^{-1}$ at $T_{1}$ is the best practice that could give the maximum net benefit and the marginal rate of return in a less rainy season.

\section{Discussion}

Erratic rainfall distribution and the amount can considerably influence the response of maize to $\mathrm{N}$ application as it may cause runoff and leaching of applied $\mathrm{N}$. Some research finding also confirmed that the yield of maize with high rainfall regimes is generally low due to poor nutrient use efficiency [18]. $\mathrm{N}$ use efficiency by the crop can be reduced under heavy rainfall, particularly at the time of application, since the nutrient can be lost through $\mathrm{NO}_{3}$ losses and even through soil erosion [19]. If the rainfall amount and distribution are relatively adequate, like in 2014 cropping season, $\mathrm{N}$ uptake by the crop could be enhanced since runoff and even leaching effect can be reduced, and hence yield production and productivity are increased [11,20]. However, the $\mathrm{N}$ use efficiency can be improved through the further split application of $\mathrm{N}$ at different growth stage absorbed by the crop since leaching is one of the main challenges for $\mathrm{N}$ loss in high rainfall areas [11, 20]. Jamal et al. [12] also indicated that about $50 \%$ at higher doses of applied $\mathrm{N}$ remains unavailable to a crop due to $\mathrm{N}$ loss through leaching in areas receiving heavy rainfall amount and uneven distribution.

In 2013, higher doses of $\mathrm{N}\left(115 \mathrm{~kg} \mathrm{ha}^{-1}\right)$ could give similar yield performance as compared to the lower $\left(69 \mathrm{~N} \mathrm{~kg} \mathrm{ha}^{-1}\right)$. This might be due to low absorption of nitrogen by the crop since $\mathrm{N}$ losses through leaching and runoff may be high as compared to adequate and even distribution of the rainfall [21]. However, this result in line with other research reports revealed that grain yield of maize due to the application of $\mathrm{N}$ in a heavy and uneven distribution of rainfall areas significantly increased compared to the control plot $[22,23]$. Application of recommended $\mathrm{N}$ half at the time of maize planting significantly reduced the yield of maize when compared with different $\mathrm{N}$ rates at a different time of application, but not at the time of planting. This result is directly related to $\mathrm{N}$ losses through leaching since the crop could not be utilized at the early emergence stage until its root development $[15,24]$. Similar findings were also reported by other authors $[11,13,16]$

The response of maize at the higher rates of $\mathrm{N}$ was observed in 2014. This might be related to rainfall amount and distribution of rainfall, particularly at the time of $\mathrm{N}$ application that may reduce the loss [24-26]. Delayed time of application after root development significantly enhanced the yield of maize compared to before or at the time of planting [25]. This is in agreement with this result that application of $\mathrm{N}$ after 10-15 days after planting onwards significantly increased yield compared with farmers' practices. $\mathrm{N}$ use efficiency even under low rates of $\mathrm{N}$ at two to three times applications considerably enhances $\mathrm{N}$ absorption in good rainy seasons [6, 27]. Moreover, time of application significantly enhances $\mathrm{N}$ absorption, particularly at the time of critical $\mathrm{N}$ requirement for the crop [11, 13]. Other reports also confirmed that split application of $\mathrm{N}$ after the good establishment of the crop markedly reduces $\mathrm{N}$ losses [16]. The lowest yield was, however, recorded from control plot receiving no $\mathrm{N}$ [6].

In line with the agreement of this result, both agronomic efficiency and HI were not significantly increased as the function of $\mathrm{N}$ rate increased and other reports were also similar [11, 13]. However, delayed application of $\mathrm{N}$ after crop establishment significantly increased $\mathrm{HI}$ compared to N application at the time of planting [24]. The highest $\mathrm{AE}$ and HI were recorded from the control plot $[11,28]$.

\section{Conclusion}

Despite the fact that maize productivity is relatively better than other major cereal crops, its current productivity is still far below its potential productivity. $\mathrm{N}$ rate and time of application are among the major abiotic factors limiting the production and productivity of the crop. Amount and distribution of rainfall across the seasons considerably influenced the responses of maize to rate and time of $\mathrm{N}$ application. In a heavy and uneven distribution of rainfall similar to 2013 cropping season, application of $92 \mathrm{~N} \mathrm{~kg} \mathrm{ha}^{-1}$ at $T_{2}(10-15$ days after planting (DAP), 35-40 DAP, and 55-60 DAP) gave comparable optimum grain yield compared to other treatment means. Even though the application of $92 \mathrm{~N} \mathrm{~kg} \mathrm{ha}^{-1}$ gave optimum grain yield in 2014 season, two times application (10-15 DAP and 35-40 DAP) was an optimum time. In conclusion, application of $92 \mathrm{~N} \mathrm{~kg} \mathrm{ha}^{-1}$ at $T 1$ is the best $\mathrm{N}$ rate and time of application to get the maximum net benefit and acceptable MRR in good rainy seasons and hence is recommended for the end users. However, in case of erratic and heavy rainy seasons that may lead to $\mathrm{N}$ losses through runoff and leaching during time of $\mathrm{N}$ application, application of $92 \mathrm{~N} \mathrm{~kg} \mathrm{ha}^{-1}$ at three times application (1/3 $\mathrm{N}$ at 10-15 DAP, $1 / 3 \mathrm{~N}$ at 35-40 DAP, and 55-60 DAP) should be used to get maximum profit and acceptable MRR.

\section{Conflicts of Interest}

The authors declare that there are no conflicts of interest regarding the publication of this paper.

\section{Acknowledgments}

The authors greatly acknowledge Oromia Agricultural Research Institute for financial support. They sincerely acknowledge Bako Agricultural Research Center for all the technical and managerial support provided during the experimental period. Great thanks also go to the research staffs of cereal research teams who were directly or indirectly involved in the execution of the experiment.

\section{References}

[1] Z. Abebe, C. Dabala, and T. Birhanu, "System Productivity as Influenced by Varieties and Temporal Arrangement of Bean in Maize-climbing Bean Intercropping," Journal of Agronomy, vol. 16, no. 1, pp. 1-11, 2016. 
[2] N. Mandefro, D. Tanner, and S. Twumasi-Afriyie, "Enhancing the contribution of maize to food security in Ethiopia in," in Proceedings of the Second National Maize Workshop of Ethiopia, pp. 12-16, Addis Ababa, Ethiopia, 2001.

[3] T. Abate, B. Shiferaw, A. Menkir et al., "Factors that transformed maize productivity in Ethiopia," Food Security, vol. 7, no. 5, pp. 965-981, 2015.

[4] Variety Registration, Crop Variety Registration, in, CVR (Crop, Addis Ababa, 2012.

[5] C. C. S. Authority, Agricultural Sample Survey for 2013/14 Crop Season.Report on Area and Production of Crops for Private and Peasant Holdings, in, Central Statistical Authority, Ethiopia, Addis Ababa, 2013.

[6] S. K. Mourice, S. D. Tumbo, A. Nyambilila, and C. L. Rweyemamu, "Modeling potential rain-fed maize productivity and yield gaps in the Wami River sub-basin, Tanzania," Acta Agriculturae Scandinavica Section B: Soil and Plant Science, vol. 65, no. 2, pp. 132-140, 2015.

[7] J. Blumenthal, D. Baltensperger, K. G. Cassman, S. Mason, and A. Pavlista, Importance and effect of nitrogen on crop quality and health, Nitrogen in the Environment: Sources, Problems, and Management, Elsevier, Oxford, 2nd edition, 2008.

[8] F. G. Fernßndez, E. D. Nafziger, S. A. Ebelhar, and R. G. Hoeft, "Managing nitrogen in. Illinois agronomy handbook. Univ. Illinois Coop. Ext. Serv," Urbana-Champaign, pp. 113-132, 2009.

[9] R. B. Nielsen, Root Development in Young Corn, in, Purdue University Department of Agronomy, 2013.

[10] R. J. Gehl, J. P. Schmidt, L. D. Maddux, and W. B. Gordon, “Corn yield response to nitrogen rate and timing in sandy irrigated soils," Agronomy Journal, vol. 97, no. 4, pp. 1230-1238, 2005.

[11] N. K. Fageria and V. C. Baligar, "Enhancing Nitrogen Use Efficiency in Crop Plants," Advances in Agronomy, vol. 88, pp. 97-185, 2005.

[12] Z. Jamal, M. Hamayun, N. Ahmad, and M. F. Chaudhary, "Effects of soil and foliar application of different concentrations of NPK and foliar application of (NH4)2 SO4 on different yield parameters in wheat," Journal of Agronomy, vol. 5, no. 2, pp. 251256, 2006.

[13] D. Haile, D. Nigussie, and A. Ayana, "Nitrogen use efficiency of bread wheat: effects of nitrogen rate and time of application," Journal of Soil Science and Plant Nutrition, vol. 12, no. 3, pp. 389409, 2012.

[14] T. Debele, G. Gedano, and M. Leul, "Response of Maize to Split Application of Nitrogen Fertilizer at Bako," in Proceedings of the in 6 Annual Conference of the Crop Science Society of Ethiopia, p. 3, 1994.

[15] H. Darby and J. Lauer, "Plant physiology—critical stages in the life of a corn plant, Field Corn,” Tech. Rep., 2004, http://www. mn. nrcs. USDA. gov/technical/ECS/pest/planning aids.

[16] J. E. Sawyer, "Nitrogen application timing, forms, and additives," American Society of Agricultural and Biological Engineers, 2008.

[17] CIMMYT, From agronomic data to farmer recommendations: an economics training manual, 1988.

[18] S. Sitthaphanit, V. Limpinuntana, B. Toomsan, S. Panchaban, and R. W. Bell, "Growth and yield responses in maize to split and delayed fertilizer applications on sandy soils under high rainfall regimes," Kasetsart Journal (Natural Science), vol. 44, pp. 9911003, 2010.

[19] J. M. Sogbedji, H. M. Van Es, C. L. Yang, L. D. Geohring, and F. R. Magdoff, "Nitrate leaching and nitrogen budget as affected by maize nitrogen rate and soil type," Journal of Environmental Quality, vol. 29, no. 6, pp. 1813-1820, 2000.

[20] R. Chikowo, P. Mapfumo, P. Nyamugafata, and K. E. Giller, "Mineral N dynamics, leaching and nitrous oxide losses under maize following two-year improved fallows on a sandy loam soil in Zimbabwe," Plant and Soil, vol. 259, no. 1-2, pp. 315-330, 2004.

[21] P. Scharf, J. Lory, and J. Grundler, "Best management practices for nitrogen fertilizer in Missouri," 2006.

[22] E. R. Thom and B. R. Watkin, "Effect of rate and time of fertiliser nitrogen application on total plant, shoot, and root yields of maize (zea mays 1.)," New Zealand Journal of Experimental Agriculture, vol. 6, no. 1, pp. 29-38, 1978.

[23] G. L. Wang, Y. L. Ye, X. P. Chen, and Z. L. Cui, “Determining the optimal nitrogen rate for summer maize in China by integrating agronomic, economic, and environmental aspects," Biogeosciences, vol. 11, no. 11, pp. 3031-3041, 2014.

[24] A. Niaz, M. Yaseen, M. Arshad, and R. Ahmad, "Response of maize yield, quality and nitrogen use efficiency indices to different rates and application timings," Journal of Animal and Plant Sciences, vol. 25, no. 4, pp. 1022-1031, 2015.

[25] L. Sangoi, P. R. Ernani, and P. R. F. Da Silva, "Maize response to nitrogen fertilization timing in two tillage systems in a soil with high organic matter content," Revista Brasileira de Ciencia do Solo, vol. 31, no. 3, pp. 507-517, 2007.

[26] O. S. Walsh, Effect of delayed nitrogen fertilization on corn grain yields, Oklahoma State University, 2006.

[27] A. Limon-Ortega, N. A. Ruiz-Torres, G. Vazquez-Carrillo, and A. Baez-Perez, "Environment and nitrogen influence on rainfed maize yield and quality," Crop Science, vol. 56, no. 3, pp. 12571264, 2016.

[28] S. Dhital and W. R. Raun, "Variability in optimum nitrogen rates for maize," Agronomy Journal, vol. 108, no. 6, pp. 2165-2173, 2016. 


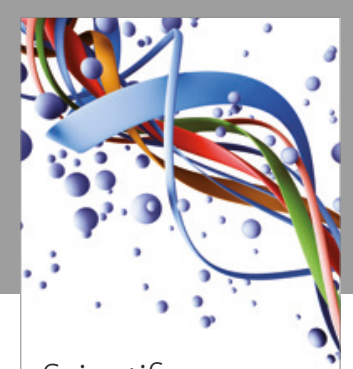

Scientifica
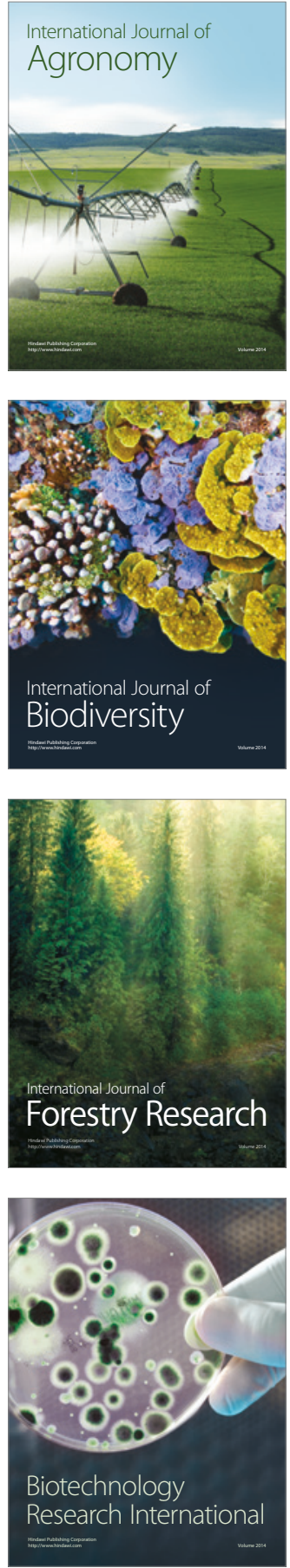
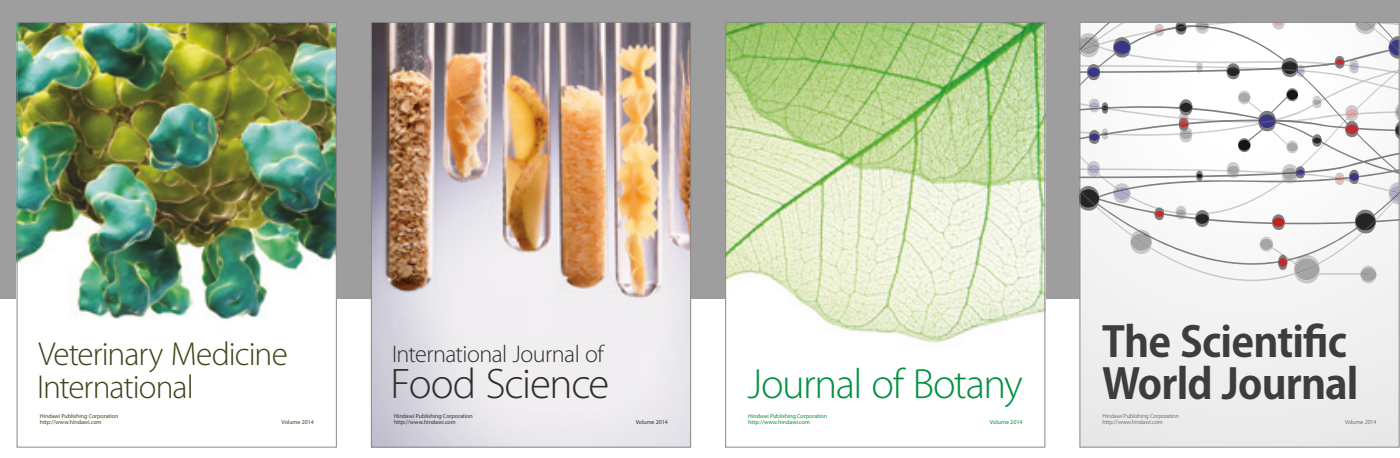

The Scientific

\section{World Journal}

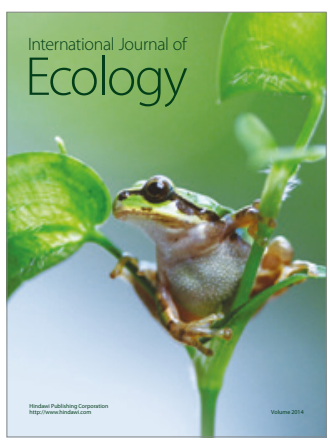

\section{Hindawi}

Submit your manuscripts at

https://www.hindawi.com
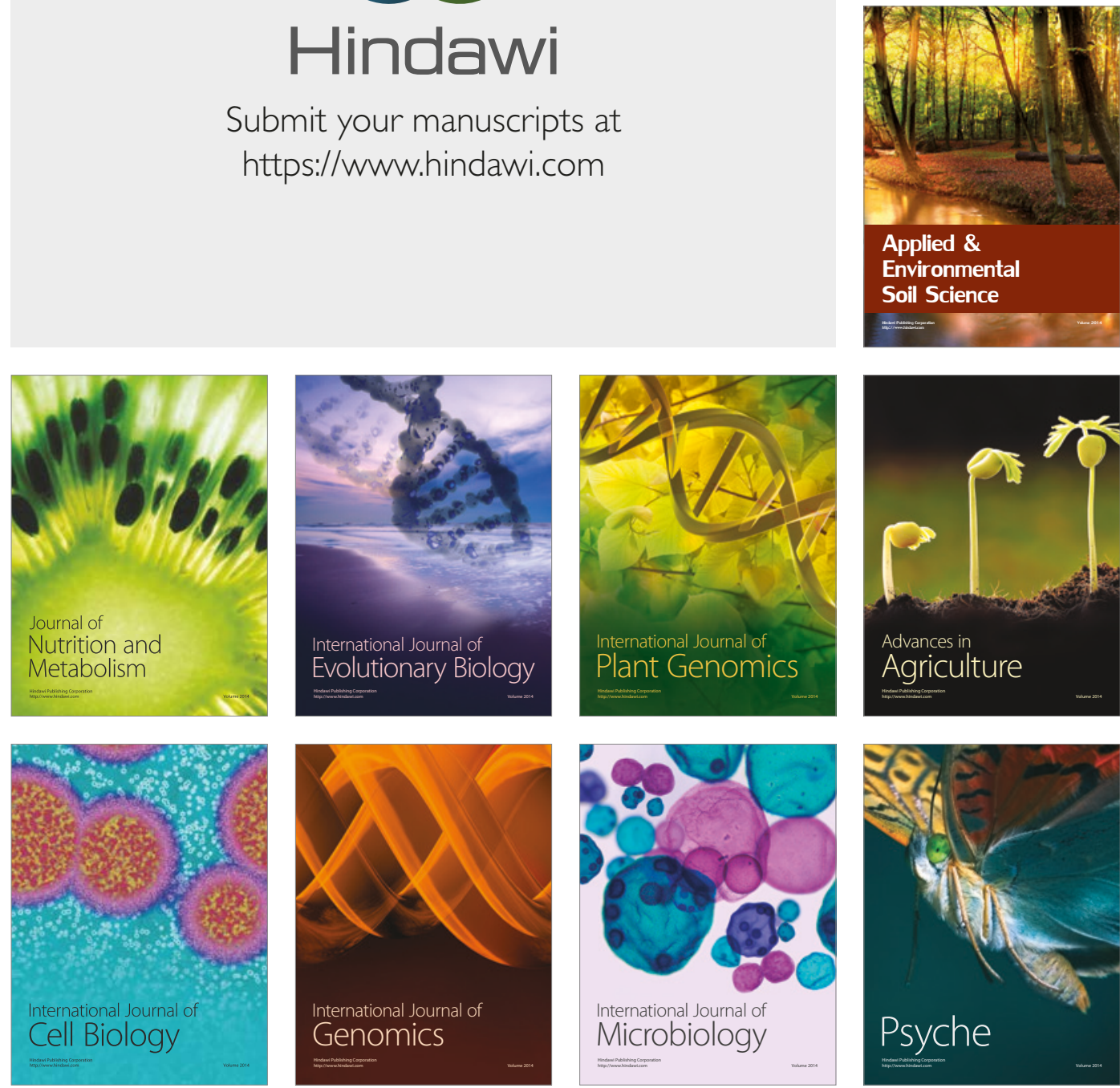

hternational Journal of Microbiology
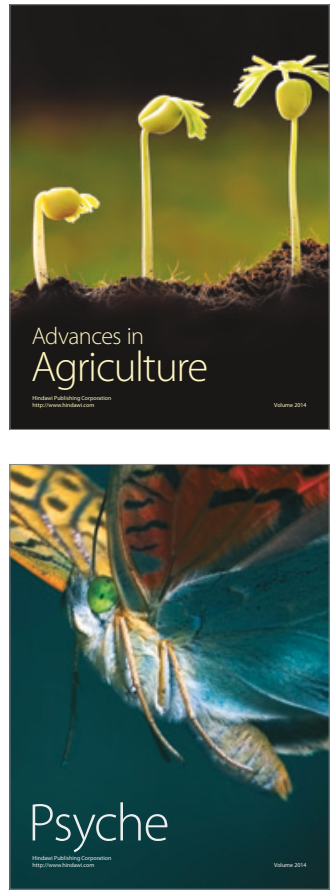